\title{
Clinical, Bacteriological, and Histopathological Study of Toxic Puerperal Metritis in Iraqi Buffalo
}

\author{
O. I. Azawi, ${ }^{11}$ S. N. Omran,, and J. J. Hadadł \\ *Department of Surgery and Obstetrics, College of Veterinary Medicine, University of Mosul, Mosul, Iraq \\ †Department of Theriogenology, College of Veterinary Medicine, University of Baghdad, Baghdad, Iraq \\ ‡Department of Microbiology, College of Veterinary Medicine, University of Dohuk, Dohuk, Iraq
}

\section{ABSTRACT}

Data were collected from 42 buffalo with toxic puerperal metritis in 2 large herds, with a history of dystocia, prolapse, and retained placenta. All buffalo were subjected to detailed clinical examination including external inspection, vaginoscopy, and transrectal palpation of the cervix, uterus, and ovaries. Swabs for bacteriology and biopsies for histopathology were collected from the uterine lumen from each cow. Character, odor, and estimation of polymorphonuclear cells of the vaginal mucus were scored. Blood samples were collected from cows for creatine kinase and aspartate aminotransferase measurement. The most predisposing factor causing toxic puerperal metritis was retained placenta $(52.4 \%)$, and the most prevalent bacteria in uterine lumen were Escherichia coli, Arcanobacterium pyogenes, Staphylococcus aureus, and Fusobacterium necrophorum (18.5, 16.7, 13.0, and 9.3\%, respectively). High levels of polymorphonuclear cells were observed in buffalo infected with $A$. pyogenes and gram-negative anaerobic bacteria (62.1 and 76.4\%). A high prevalence of gram-negative anaerobes was isolated from uteri harboring A. pyogenes (13.0\%). Buffalo with toxic puerperal metritis had significantly higher creatine kinase and aspartate aminotransferase activities than controls $(499.2 \pm 23.9$ and $208.3 \pm 11.3$ vs. $242.7 \pm 12.9$ and $166.8 \pm 11.5 \mathrm{U} / \mathrm{L}$, respectively). In a conclusion, gramnegative anaerobes and other facultative pathogens including $A$. pyogenes were important pathogens that cause severe uterine inflammation.

Key words: buffalo cow, toxic puerperal metritis, bacteriology, enzyme

\section{INTRODUCTION}

Toxic puerperal metritis is one of the most important diseases in buffalo with high mortality rate postpartum

Received February 14, 2007.

Accepted June 14, 2007.

${ }^{1}$ Corresponding author: azawihh@yahoo.com
(Jainudeen, 1986). Toxic puerperal metritis (i.e., acute septic metritis) is characterized by increased rectal temperature, depression, anorexia, and fetid watery vulvar discharge (Paisley et al., 1986; Smith et al., 1998). Buffaloes with toxic puerperal metritis usually die within a few days or sometimes recover. In this species, the related knowledge available is very limited, and studies concerning incidence and mortality rate of buffalo cows infected with toxic puerperal metritis have not been published. Buffaloes recovering from toxic puerperal metritis, established metritis, or endometritis can become chronic (Melendez et al., 2004), causing high economic losses due to prolonged days open and prolonged intercalving interval, resulting in involuntary culling (Jainudeen, 1986; Karimi et al., 2004).

Following parturition, the uterus of more than $90 \%$ of all cows becomes contaminated with bacteria (Griffin et al., 1974), which seems characteristics of uterine involution in dairy cows (Paisley et al., 1986). Yet, if lochia becomes fetid and dark brown, toxic puerperal metritis could be a severe problem, and uterine infections that are life threatening are associated almost exclusively with this condition (Slama et al., 1991; Smith et al., 1998). The uterus of postpartum buffalo is usually contaminated with a range of bacteria, but this is not consistently associated with clinical disease. Infection implies adherence of pathogenic organisms to the mucosa, colonization or penetration of the epithelium, release of bacterial toxins that lead to establishment of uterine disease, or a combination of these (Sheldon et al., 2006). The postpartum uterus has a disrupted surface epithelium in contact with fluid and tissue debris that can support bacterial growth (Etherington et al., 1985; Konigsson et al., 2002). The outcome of uterine contamination depends on the number and virulence of the organisms present (Cohen et al., 1995), as well as the condition of the uterus and its inherent defense mechanism (Hussain, 1989). Buffaloes with certain calving problems have a reduced ability to control uterine infections. Excessive stretching of the uterus, with traumatization of genital tissues during dystocia or obstetrical manipulation, and some tradi- 
tional practices by farmers and herdsmen of inserting the hand or implements in the vagina of buffalo cows to stimulate milk letdown, as well as unhygienic conditions under which animals are allowed to calve, can diminish uterine tonus. Lochia is then retained beyond the normal period, providing a medium for bacterial multiplication (Noakes et al., 2002). Phagocytosis by uterine leukocytes is reduced in cows with dystocia and retained fetal membranes (Paisley et al., 1986). If the uterus is severely debilitated, any of a variety of contaminating organisms can cause a toxic puerperal metritis (Smith et al., 1998). The present study was designed to determine the relationship between bacteriological findings, clinical signs, and histopathological changes in Iraqi buffalo cows infected with toxic puerperal metritis.

\section{MATERIALS AND METHODS}

\section{Animals}

The study began in September 2004 and continued until January 2006. It was conducted on lactating Iraqi northern buffalo cows in 2 large private herds in Nineveh province. Buffalo cows infected with toxic puerperal metritis calved recently ( 4 to $10 \mathrm{~d}$ ) and were aged 5 to $15 \mathrm{yr}$. All buffalo cows with toxic puerperal metritis (42 animals) and control group (6 animals) were of the local Iraqi northern breed. These 2 private buffalo dairy herds consisted of approximately 180 and 250 buffalo. The animals were kept outdoors near the rivers for wallowing and were milked twice daily. A balanced nutritional diet including green fodder and concentrated mixture were fed to these cows. Animals with history of caesarean section, acute mastitis, lameness, abdominal disorders or other undercurrent diseases were excluded on the basis of clinical examinations to remove conflicting influences of nonuterine bacterial infection. The following data were recorded of each buffalo cow: name of buffalo, breed, parity, obstetrical problems, type of last parturition, retained placenta, vaginal prolapse, uterine prolapse, abortion, and milk production. A control group consisted of 6 buffalo cows that calved normally and expelled their fetal membranes within $12 \mathrm{~h}$ postpartum with no abnormal clinical signs.

\section{Clinical Examinations}

The general health status, appetite, rectal temperature, pulse rate, respiration rate, and other clinical signs such as arched back, colic, pain, paresis, and presence of fresh discharge on the vulva, perineum, or tail were recorded. Rectal examination of uterus, oviducts, ovaries (if palpable), and cervix was performed on each buffalo cow. The vulva was wiped with damp clean tow- els, disinfected with iodine-povidine, and washed again with water. A sterile vaginal speculum was lubricated with sterile petroleum jelly and inserted into the vagina to the level of the external os of the cervix. Inspection of the cervix and vagina was performed with illumination from a penlight. The examination lasted for 5 to $30 \mathrm{~s}$. Buffalo cows diagnosed with toxic puerperal metritis were required to meet the following 2 criteria: 1 ) cows must have been febrile (i.e., rectal temperature $>39^{\circ} \mathrm{C}$ ) and 2) have had a flaccid, nonretractable uterus located in the abdomen, a cervical diameter $>7.5 \mathrm{~cm}$, and a watery, fetid vulval discharge.

\section{Uterine Swab Collection and Bacteriology}

Sampling for bacteriological examination was performed immediately after clinical examination and diagnosis of toxic puerperal metritis. The vulval lips were parted, and an outer protective sterile plastic straw sheath was advanced into the vagina and fixed in the external opening of the cervix. A guarded inseminating pipette was advanced through the outer tube into the uterus by cervical manipulation similar to the technique for AI. The sterile swab was pushed out of its protective sterile plastic sheath (to protect from contamination with cervix) and moved about slightly in the body of the uterus. After retraction into its cover, the swab was removed from the vagina. Swabs were transferred into sterile tubes containing thioglycolate broth as a transport media, transported to the laboratory at $4^{\circ} \mathrm{C}$, and processed for bacteriological examination. Swabs were cultured aerobically on sheep blood agar, MacConkey agar, and nutrient agar and anaerobically on sheep blood agar. Bacteria were identified after a 24 -h incubation at $37^{\circ} \mathrm{C}$ for aerobic growth and 7-d incubation for anaerobic bacterial growth. Identification was based on the characteristic of colony, hemolysis, gram stain, morphology, the catalase, coagulase, oxidase, indole production, methyl red, Voges-Proskauer, and citrate production tests and sugar utilization, and confirmed by the analytical profile index system (API 20E, API 20A, API Coryn, API Staph, API Strep) supplied by bioMérieux SA (Marcy l'Etoile, France). Some isolates were reconfirmed by sending these isolates to the Central Health Laboratory, Ministry of Health, Baghdad, Iraq. A total of 42 samples were collected from sick animals and 6 samples from the control group with normal puerperium.

\section{Biopsy Collection and Histopathology}

Biopsies were obtained following the culturing procedure. Two separate tissue samples were obtained from each uterine horn (gravid and nongravid) with the bi- 
Table 1. Clinical findings of buffalo cows undergo routine reproductive examinations including toxic puerperal metritis

\begin{tabular}{|c|c|c|}
\hline \multirow[b]{2}{*}{ Finding } & \multicolumn{2}{|c|}{ Toxic puerperal metritis } \\
\hline & Infected $\pm \mathrm{SE}(\mathrm{n})$ & Control $\pm \mathrm{SE}(\mathrm{n})$ \\
\hline Rectal temperature $\left({ }^{\circ} \mathrm{C}\right)$ & $40.9 \pm 0.2^{*}$ & $38.1 \pm 0.1$ \\
\hline Respiration rate (per min) & $52.3 \pm 4.7^{*}$ & $33.8 \pm 1.9$ \\
\hline Pulse rate (per min) & $112.7 \pm 8.3^{*}$ & $75.6 \pm 4.9$ \\
\hline Visible pus on external examination (\%) & $54.8(23)$ & Lochia \\
\hline Visible pus by vaginoscopy (\%) & $45.2(19)$ & Lochia \\
\hline \multicolumn{3}{|l|}{ Character of discharge } \\
\hline 1-None & 0 & Lochia \\
\hline 2-Clear mucus & 0 & Lochia \\
\hline 3-Clear mucus with flakes of pus & 0 & Lochia \\
\hline 4-Mucopurulent & 0 & Lochia \\
\hline 5-Purulent with no fetid smell & 0 & Lochia \\
\hline 6-Purulent with fetid smell & $100(42)$ & Lochia \\
\hline \multicolumn{3}{|l|}{ Cervical diameter $(\%)$} \\
\hline $1-\leq 5 \mathrm{~cm}$ & 0 & 0 \\
\hline $2-5$ to $7.5 \mathrm{~cm}$ & $21.4(9)$ & $100(6)$ \\
\hline $3 \rightarrow 7.5 \mathrm{~cm}$ & $78.6(33)$ & 0 \\
\hline \multicolumn{3}{|l|}{ Location of uterus (\%) } \\
\hline $1-$ In pelvis & 0 & 0 \\
\hline 2-Over pelvic brim & 0 & 0 \\
\hline 3-Non-retractable & $100(42)$ & $100(6)$ \\
\hline \multicolumn{3}{|l|}{ Symmetry of horns (\%) } \\
\hline $1-Y e s$ & 0 & 0 \\
\hline $2-\mathrm{No}$ & $100(42)$ & $100(6)$ \\
\hline \multicolumn{3}{|l|}{ Thickness of uterine wall (\%) } \\
\hline 1-Yes (thin) & 0 & 0 \\
\hline 2-No (thick) & $100(42)$ & $100(6)$ \\
\hline
\end{tabular}

opsy instrument (approximately $1 \mathrm{~cm}^{3}$ ). The endometrial biopsies were immediately placed into bottles containing $10 \%$ formal saline solution and stored at $4^{\circ} \mathrm{C}$ until preparation as the methods described by Luna (1968).

\section{Estimation of Polymorphonuclear Cells}

A fluid aliquot (2 to $3 \mathrm{~mL}$ ) was collected from each cow. The fluid was aspirated from the uterine lumen using sterile uterine catheter and transferred into sterile tubes, then transported to the laboratory at $4^{\circ} \mathrm{C}$ for the determination of the percentage of polymorphonuclear (PMN) cells (Kasimanickam et al., 2005). Smears were prepared from the uterine fluid, fixed with absolute methyl alcohol and stained by Wright-Giemsa stain. Two stained smears per sample were used and the average of the 2 readings was used in statistical analysis. Samples were taken before treatment of buffalo cows infected with toxic puerperal metritis.

\section{Blood Sampling and Enzyme Assays}

Blood samples were collected from the jugular vein. Serum samples were collected after centrifugation at $700 \times g$ for $10 \mathrm{~min}$. Serum samples were transferred in plastic tubes and stored at $-20^{\circ} \mathrm{C}$ until enzymatic analysis. Aspartate amino transferase (AST) activity was estimated using the Lab kit (Labkit-Josep Tarradellas, 8008029, Barcelona, Spain), and a spectrophotometer at wavelength of $340 \mathrm{~nm}$. The absorbance was recorded 3 times, 1 min apart, and the mean of the 3 readings was used as the enzymatic activity. Creatine kinase (CK) was estimated using the kit CK-NAC (BIOLAB SA, Les Hautes Rivers, 02160 Maizy-France). The catalytic activity of CK was determined by the increase in the absorbance at $340 \mathrm{~nm}$ wavelength of a spectrophotometer by reading the initial absorbance after 120 $\mathrm{s}$, followed by 3 readings $1 \mathrm{~min}$ apart, and finally calculating the absorbance change per minute $(\Delta \mathrm{A} / \mathrm{min})$ using the equation CK-activity $\mathrm{U} / \mathrm{L}=\Delta \mathrm{A} / \mathrm{min} \times 333$.

\section{Statistical Analysis}

Statistical analyses were performed with the software (Sigma Sat, 2004; Jandel Scientific Software, v.2.0, Richmond, CA). The enzymatic activities of CK and AST and PMN were tested by the ANOVA and LSD. Student's 2 -sample $t$-test was performed for the difference between 2 means of rectal temperature, pulse rate, and respiration rate. For the determination of correlation coefficient between isolates and histopathological changes of 2 variables, the Pearson product moment correlation analysis was used. The differences in 
Table 2. Prevalence of bacterial isolates from the uterus of buffalo cows with toxic puerperal metritis

\begin{tabular}{|c|c|c|c|c|}
\hline \multirow[b]{2}{*}{ Bacterial isolate } & \multicolumn{2}{|c|}{$\begin{array}{l}\text { Toxic puerperal } \\
\text { metritis }\end{array}$} & \multicolumn{2}{|c|}{$\begin{array}{l}\text { Control } \\
\text { group }\end{array}$} \\
\hline & $\mathrm{n}$ & $\%$ & $\mathrm{n}$ & $\%$ \\
\hline Arcanobacterium pyogenes & 18 & 16.7 & 1 & 7.1 \\
\hline Bacillus licheniformis & 4 & 3.7 & 2 & 14.3 \\
\hline Prevotella melaninogenicus & 6 & 5.6 & - & - \\
\hline Citrobacter braakii & 2 & 1.9 & - & - \\
\hline Citrobacter freundii & 2 & 1.9 & - & - \\
\hline Clostridium tetani & 6 & 5.6 & - & - \\
\hline Escherichia coli & 20 & 18.5 & 4 & 28.6 \\
\hline Fusobacterium necrophorum & 10 & 9.3 & - & - \\
\hline Klebsiella pneumoniae & 3 & 2.8 & - & - \\
\hline Lactobacillus fermentus & - & - & 1 & 7.1 \\
\hline Peptococcus niger & 4 & 3.7 & - & - \\
\hline Proteus mirabilis & 2 & 1.9 & 2 & 14.3 \\
\hline Pseudomonas aeruginosa & 2 & 1.9 & 2 & 14.3 \\
\hline Staphylococcus aureus & 14 & 13.0 & 2 & 14.3 \\
\hline Staphylococcus epidermidis & 5 & 4.6 & - & - \\
\hline Streptococcus intermedius & 1 & 0.9 & - & - \\
\hline Streptococcus pyogenes & 4 & 3.7 & - & - \\
\hline Streptococcus uberis & 5 & 4.6 & - & - \\
\hline Total & 108 & 100 & 14 & 100 \\
\hline
\end{tabular}

percentages of reproductive problems were tested by $\chi^{2}$ analysis.

\section{RESULTS}

The results revealed that all buffalo cows with toxic puerperal metritis had a history of obstetrical problems including dystocia $(\mathrm{n}=6 ; 14.3 \%)$, retention of fetal membranes $(n=22 ; 52.4 \%)$, vaginal prolapse $(n=1 ; 2.4 \%)$, uterine prolapse $(\mathrm{n}=5 ; 11.9 \%)$, and using some traditional methods for milk let down $(\mathrm{n}=8 ; 19.1 \%)$.

Clinical examinations of cows with toxic puerperal metritis indicated anorexia, depression, staggering gait, paresis, difficulty in rising, constipation with black scanty feces, frequent and recurrent painful straining, rectal temperature of $40.9 \pm 0.18^{\circ} \mathrm{C}$, pulse rate of 12.7 $\pm 8.33 / \mathrm{min}$, and respiration rate $52.3 \pm 4.7 / \mathrm{min}$ were higher $(P<0.05)$ than control group (Table 1$)$. On vaginal examination, there is a watery fetid bloody-brownish discharge in all animals infected with toxic puerperal metritis. The genital tracts of buffalo when examined per rectum revealed high percentage $(78.6 \%)$ of cervical diameter $>7.5 \mathrm{~cm}$ with nonretractable highly enlarged asymmetrical horns. The uterine walls were atonic, thick, and without signs of involution.

The variety and prevalence of bacterial isolates from buffalo cows with toxic puerperal metritis and the control group are in Table 2. Between the isolates, Escherichia coli (18.5\%), Arcanobacterium pyogenes (16.7\%), Staphylococcus aureus (13.0\%), and Fusobacterium necrophorum (9.3\%) were the most prevalent isolates in diseased postpartum uterus. In the control group, $E$.

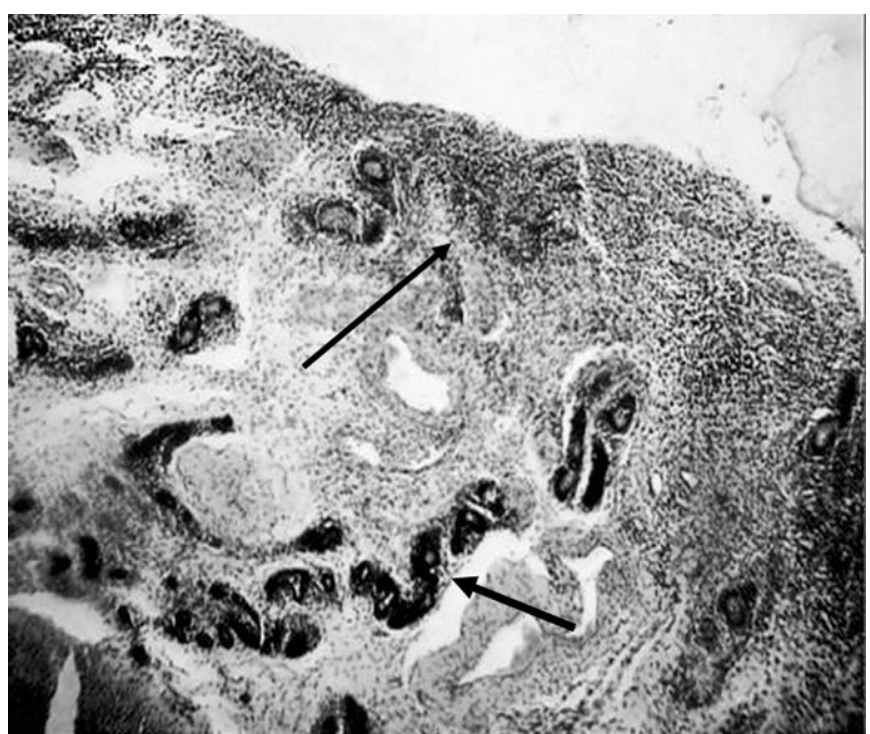

Figure 1. Toxic puerperal metritis, massive infiltration of polymorphonuclear cells (upper arrow) with extensive hemorrhages (lower arrow; hemotoxylin and eosin stain; magnification $\times 200$ ).

coli was the dominant bacteria in the uterus. All the isolates recovered from the uterus of buffalo cows with toxic puerperal metritis were mixed isolates, and no single isolate was found in the uterus. Only 1 cow in the control group had a single isolate of $E$. coli.

Histopathological examination of the endometrium of all buffalo with toxic puerperal metritis showed acute endometritis associated with massive infiltration of multinucleated inflammatory cells around uterine glands and blood vessels, hyperemia in blood vessels, thrombus formation in blood vessels with hemorrhage in different sites of stroma (Figure 1). The most prevalent bacterial isolates in the uterus with the above mentioned severe histological changes were $A$. pyogenes and $F$. necrophorum. Staining biopsies from animals harboring $E$. coli in their uterus indicated by standard bacteriological procedures, and using modified gram stain for histological examination revealed massive infection and colonization of $E$. coli in the subendometrial region of the uterine tissue (Figure 2).

The percentage of PMN $(68.8 \pm 6.3 \%)$ was higher $(P$ $<0.01$ ) in buffalo cows with toxic puerperal metritis than the control group $(31.7 \pm 5.7 \%)$. The PMN was correlated $(\mathrm{r}=0.894 ; P<0.01)$ with the character of vaginal discharge. In addition, an association was found between type of isolate and PMN. A high percentage of $\mathrm{PMN}$ was found in samples infected with gram-negative anaerobic bacteria (76.4\%) and A. pyogenes (62.1\%). Results of bacterial isolations from infected uteri indicated a high prevalence of gram-negative anaerobic bacteria when these samples harbored A. pyogenes (Figure 3 ). 


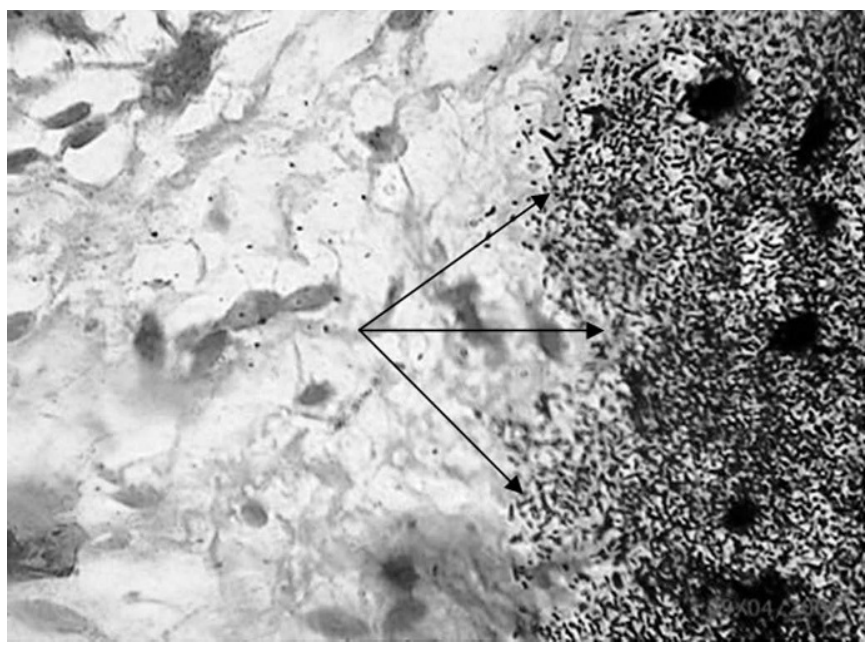

Figure 2. Colonization of Escherichia coli (arrows) in uterine endometrium from a buffalo cow with toxic puerperal metritis (modified gram stain; magnification $\times 1,000$ ).

Buffalo cows with toxic puerperal metritis had higher CK (499.2 \pm 23.8 vs. $208.3 \pm 11.3 \mathrm{U} / \mathrm{L})$ and AST $(242.7$ \pm 12.9 vs. $166.8 \pm 11.5 \mathrm{U} / \mathrm{L})$ activities $(P<0.01)$ than control animals with normal puerperium.

\section{DISCUSSION}

The predisposing factor leading to the development of uterine infections was the retention of placenta, and it was associated with $52.4 \%$ of buffalo cows afflicted with toxic puerperal metritis, whereas the lowest risk factor was vaginal prolapse (2.4\%). This is in accord with previous results in cattle (Sandalas et al., 1979), showing the incidence of uterine infection was 25 times higher in cows with retained fetal membranes than the normal cows. Kaneene and Miller (1995) demonstrated a significant statistical association between retention of fetal membranes and metritis. Retained fetal membrane is a reproductive abnormality unique to the cow and water buffalo (Laven and Peters, 1996). Konigsson et al. (2001) suggested that retention of fetal membranes is the most important cause for postpartum metritis in dairy cows. The unshed placenta interferes with the uterine contractility and provides bacteria with substrates for rapid growth and colonization in the endometrium as shown in Figure 2. The majority of postpartum inflammatory conditions of the uterus begin with bacterial contamination of the uterine lumen. Retained placenta reduced uterine immunity by impaired uterine function (Kimura et al., 2002). The occurrence of toxic puerperal metritis was during the 4 - to 10 -d early postpartum period that is in agreement with others (Bekana et al., 1997). In addition, Olson et al. (1986) found that a life-threatening infection occurs almost exclusively during the puerperal period and defined the period from the time of calving until 7 to $14 \mathrm{~d}$ postpartum. The development of toxic puerperal metritis within $72 \mathrm{~h}$ of calving is likely due to infection by highly pathogenic organisms and to poor resistance of buffalo cows or to the occurrence of multiple predisposing factors in these animals (Sheldon et al., 2006).

There are many gaps in the knowledge of bacterial causes of uterine infection of buffalo during peripartum and postpartum period, which must be filled by isolation and identification of bacteria causing uterine infection. The bacteriological findings of the present study support earlier reports in cattle; however, there is a difference established in the prevalence of some bacteria isolated from the uterus of buffalo (Griffin et al., 1974; Huszenicza et al., 1999; Dohmen et al., 2000) as compared with cattle. Bacterial isolation from buffalo cows with toxic puerperal metritis included mainly $E$. coli, A. pyogenes, Staph. aureus, and $F$. necrophorum. Bacterial isolation from buffalo cows with normal puerperium was principally $E$. coli, Bacillus licheniformis, Proteus mirabilis, Pseudomonas aeruginosa, and Staph. aureus. Other bacteria including Prevotella melaninogenicus, Citrobacter braakii, Citrobacter freundii, Clostridium tetani, F. necrophorum, Peptococcus niger, Staphylococcus epidermidis, Streptococcus pyogenes, and Streptococcus uberis were never isolated from the genital tract of buffalo with normal puerperium (control group). Similar results were reported by (Jadon et al., 2005) and in dairy cows by (Bekana et al., 1997). Arcanobacterium pyogenes and $E$. coli with many others like Staphylococcus spp., Streptococcus spp., and Proteus spp. are frequently isolated from cows with retained placenta and cows with acute metritis (Lohuis et al., 1994). Our results indicated that $E$. coli and $A$. pyogenes were mainly present in diseased postpartum uteri. Escherichia coli could penetrate the epithelial layer of endometrium and colonize the subepithelial region of endometrium (Figure 2). It could be suggested that bacterial contamination is mainly $E$. coli in uterus after parturition as shown by the high prevalence of $E$. coli in cows in the control group. The $E$. coli penetration and colonization in the endometrium might favor the development of uterine infection by other highly pathogenic organisms such as $A$. pyogenes and $F$. necrophorum. Huszenicza et al. (1999) reported that E. coli dominated the uterus within first days after calving. Abnormal calving and retained placenta predisposes the uterus to invasion by bacteria as shown in the present study. Streptococcus pyogenes isolated from the uterus of buffalo is the first isolation of this species of bacteria in the reproductive tract of buffalo. The presence of this microorganism might be due to the contamination of 


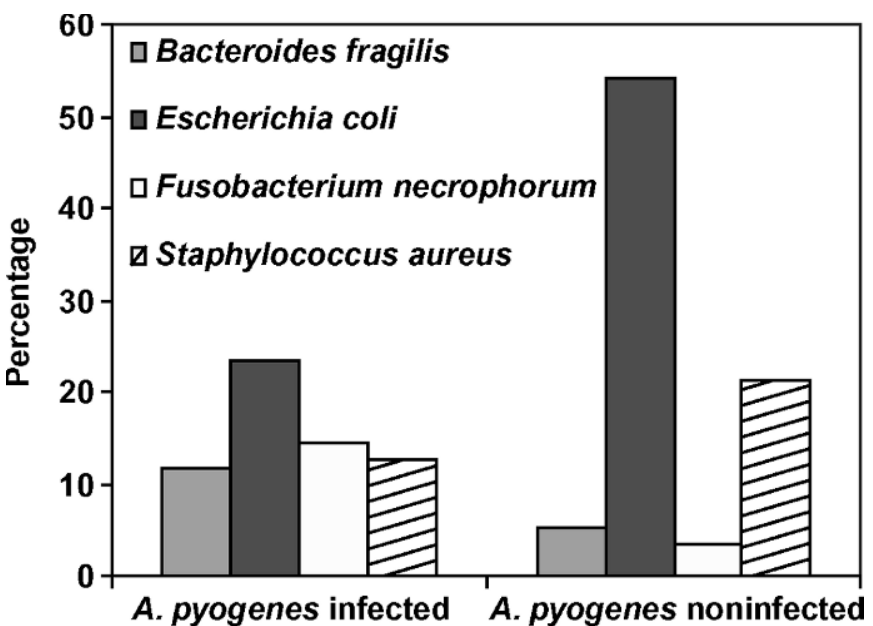

Figure 3. Bacteriology of uterine swabs from buffalo cows infected with Arcanobacterium pyogenes.

the genital tract from inserting clothes or implements of humans in the vaginal cavity for milk let down.

The period immediately after calving is very important in the reproductive life cycle of a buffalo cow because of its vast influence on reproductive efficiency. A normal uterine involution and the reestablishment of the ovarian function postpartum are crucial to obtaining a short calving to conception interval that is required to optimize milk and calf production. From bacteriological studies of toxic puerperal metritis of buffalo cows, it can be suggested that uterine inflammation occurred because of ascending contamination by nonspecific environmental organisms. More than $90 \%$ of uteri are contaminated in the first days postpartum (Bondurant, 1999). Calving insults, including dystocia, uterine prolapse, and retained fetal membranes, diminish uterine ability to eliminate contaminated organisms.

The enzyme activity of CK and AST in the serum agreed with Sattler and Furll (2004) in dairy cows, who observed elevation of CK and AST in the serum of cows with uterine infection. The CK and AST activities had not been studied in buffalo cows. The elevations of serum CK and AST in buffalo with toxic puerperal metritis might be due to the destruction of cells in the uterine wall, which can induce an increase in serum CK and AST. From the data, it could be concluded that CK and AST activities in serum of buffalo cows with toxic puerperal metritis could be a valuable aid for the determination of uterine tissue destruction.

It could be concluded that retention of fetal membranes was the most important factor leading to uterine infection and toxic puerperal metritis occurring during the early postpartum period, and that uterine inflam- mation occurs because of postpartum ascending contamination by nonspecific environmental organism. $A r$ canobacterium pyogenes and $F$. necrophorum were the most common uterine pathogens directly associated with severe histological changes. Nonspecific bacteria when isolated in high-density growth indicated diseased uteri. Clinical findings of animals with toxic puerperal metritis revealed anorexia, depression, staggering gait, paresis, difficulty in rising, constipation with black scanty feces, frequent and recurrent painful straining, and high rectal temperature, pulse rate, and respiration rate. Buffalo cows with toxic puerperal metritis had higher CK and AST activities.

\section{REFERENCES}

Bekana, M., P. Jonsson, and H. Kindahl. 1997. Bacterial isolates associated with retained fetal membranes and subsequent ovarian activity in cattle. Vet. Rec. 40:232-234.

Bondurant, R. H. 1999. Inflammation in the bovine female reproductive tract. J. Anim. Sci. 77:101-110.

Cohen, R. O., M. Bernstein, and G. Ziv. 1995. Isolation and antimicrobial susceptibility of Actinomyces pyogenes recovered from the uterus of dairy with retained fetal membranes and postparturent endometritis. Theriogenology 43:1389-1397.

Dohmen, M. J. W., K. Joop, A. Strurk, P. E. J. Bols, and J. A. C. M. Lohuis. 2000. Relationship between intra-uterine bacterial contamination endotoxin levels and the development of endometritis in postpartum cows with dystocia or retained placenta. Theriogenology 54:1019-1032.

Etherington, W. C., W. T. Bosu, and S. W. Martin. 1985. Reproductive performance in dairy cows following postpartum treatment with GnRH and/or PGF2 $\alpha$ : A field trail. Can. J. Comp. Med. 48:245-250.

Griffin, J. F. T., P. J. Hartigan, and W. R. Nunn. 1974. Nonspecific uterine infection and bovine fertility. Theriogenology 1:107-114.

Hussain, A. M. 1989. Bovine uterine defense mechanisms: A review. J. Vet. Med. B 36:641-651.

Huszenicza, G., M. Fodor, M. Gags, M. Kucsar, M. J. W. Dohmen, M. Varmos, L. Porkolas, T. Kegel, J. Bartyik, J. C. M. Lohuis, and S. Janos. 1999. Uterine bacteriology, resumption of cyclic ovarian activity and fertility in postpartum cows kept in largescale dairy herd. Reprod. Domest. Anim. 34:237-245.

Jadon, R. S., G. S. Dhaliwal, and S. K. Jand. 2005. Prevalence of aerobic and anaerobic bacteria during peripartum period in normal and dystocia infected buffaloes. Anim. Reprod. Sci. 88:215-224.

Jainudeen, M. R. 1986. Reproduction in water buffalo. Pages 443449 in Current Therapy in Theriogenology. D. A. Morrow, ed. W.B. Saunders, Philadelphia, PA.

Kaneene, J. B., and R. Miller. 1995. Risk factors for metritis in Michigan dairy cattle using herd-and cow-based modeling approaches. Prev. Vet. Med. 23:183-189.

Karimi, H. I., H. A. I. Manspeaker, R. Anvari, A. F. Moradina, A. I. Neamattillahi, and K. Niksam. 2004. The study of important factors on reproduction of Azerbaijan buffaloes (Bubalus bubalis). Page 613 in Proc. 23rd World Buiatrics Congr., Québec, Canada.

Kasimanickam, R., T. E. Duffield, R. A. Foster, C. J. Gartley, K. E. Leslie, J. S. Walton, and W. H. Johnson. 2005. A comparison of the cytobrush and uterine lavage techniques to evaluate endometrial cytology in clinically normal postpartum dairy cows. Can. Vet. J. 46:255-259.

Kimura, K., P. Jesse, O. Goff, M. E. Kehreli, and T. Reinhardt. 2002. Decreased neutrophil function as a cause of retained placenta in dairy cattle. J. Dairy Sci. 85:544-550.

Konigsson, K., H. Gustafsson, A. Gunnarsson, and H. Kindahl. 2001. Clinical and bacteriological aspects on the use of oxytetracycline 
and flunixin in primiparous cows with induced retained placenta and postpartal endometritis. Reprod. Domest. Anim. 36:247-256.

Konigsson, K., H. Gustafsson, and H. Kindahl. 2002. 15-ketodihdroPGF2 $\alpha$, progesterone and uterine involution in primiparous cows with induced retained placenta and post partal endometritis. Reprod. Domest. Anim. 37:43-51.

Laven, R. A., and A. R. Peters. 1996. Bovine retained placenta: Etiology, pathogenesis and economic loss. Vet. Rec. 139:465-471.

Lohuis, J. A. C. M., M. J. W. Dohmen, P. Nagy, C. Huszenicza, and D. Ague. 1994. Bacteriological and clinical findings in cows with subacute/chronic endometritis. Pages 97-103 in Proc. 6th Ind. EAVPT, Edinburgh, Scotland.

Luna, L. G. 1968. Histological staining methods of the armed forces institute of pathology. 3rd ed., McGraw-Hill Books, New York, NY

Melendez, P., J. McHale, J. Bartolome, L. F. Archbald, and G. A. Donovan. 2004. Uterine involution and fertility of Holstein cows subsequent to early postpartum PGF2 $\alpha$ treatment for acute puerperal metritis. J. Dairy Sci. 87:3238-3246.

Noakes, D. E., T. J. Parkinson, G. C. W. England, and G. H. Arthur. 2002. Arthur's Veterinary Reproduction and Obstetrics. 8th ed. Elsevier Sci. Ltd., London, UK.
Olson, J. D., K. N. Bretzlaff, R. G. Mortimer, and L. Ball. 1986. The metritis-pyometra complex. Pages 227-236 in Current Therapy in Theriogenology. D. A. Morrow, ed. W.B. Saunders Co., Philadelphia, PA.

Paisley, L. G., W. D. Mickelsen, and P. B. Anderson. 1986. Mechanisms and therapy for retained fetal membranes and uterine infections of cows: A review. Theriogenology 25:353-381.

Sandalas, W. C., R. A. Curtis, J. F. Cote, and S. W. Martin. 1979. The effect of retained placenta and metritis complex on reproductive performance in dairy cattle-A case control study. Can. Vet. J. 20:12-16.

Sattler, M., and H. Furll. 2004. Creatine kinase and aspartate aminotransferase in cows as indicators for endometritis. J. Vet. Med. A 51:132-137.

Sheldon, I. M., S. L. Lewis, S. LeBlanc, and R. O. Gilbert. 2006. Defining postpartum uterine disease in cattle. Theriogenology 65:1516-1530.

Slama, H., D. Vaillancourt, and A. D. Goff. 1991. Pathophysiology of the puerperal period: Relationship between PGE2 and uterine involution in the cow. Theriogenology 36:1071-1090.

Smith, B. I., G. A. Donovan, C. A. Risco, C. R. Young, and L. H. Stauken. 1998. Serum haptoglobin concentration in Holstein dairy cattle with toxic puerperal metritis. Vet. Rec. 128:83-85. 